\title{
In vitro Analysis of Antimicrobial Susceptibility of Xanthomonas axonopodis pv. punicae and Comparative Study of Protein Profiling under Biotic Stress
}

\author{
P. N. Gaikwad ${ }^{1 *}$, R. H. Autade ${ }^{1}$, B. B. Ghorpade ${ }^{1}$, R. S. Chavan ${ }^{1}$, A. A. Ghane ${ }^{1}$ \\ and D. K. Sarode ${ }^{1}$ \\ ${ }^{1}$ College of Agricultural Biotechnology, Loni (413736), Tal- Rahata, Dist- Ahmednagar, Maharashtra,
} India.

Authors' contributions

This work was carried out in collaboration among all authors. All authors read and approved the final manuscript.

Article Information

DOI: 10.9734/ARRB/2019/v32i530096

Editor(s):

(1) Dr. George Perry, Dean and Professor of Biology, University of Texas at San Antonio, USA.

Reviewers:

(1) V. Vasanthabharathi, Annamalai University, India.

(2) Isaac Kojo Arah, Ho Technical University, Ghana. Complete Peer review History: http://www.sdiarticle3.com/review-history/41166

Original Research Article

Received 15 March 2018

Accepted 26 April 2018

Published 17 August 2019

\section{ABSTRACT}

Bacterial blight of pomegranate caused by $X$. axonopodis pv. Punicae (XAP) assumed epidemic form and resulted in economic burden on farmers. In the current study the pathogen infected samples were collected and the isolated $X A P$ was identity and confirmed through the morphological, biochemical characterization and Pathogenicity test. Bacterium was reisolated from infected plant to prove Koch's postulates. Efficacy of different chemicals and oils were tested by disc diffusion assay and turbidometrically. Bronopol $3000 \mathrm{ppm}(25.6 \pm 1.6 \mathrm{~mm})$ and Clove oil $(18.0 \pm 0.7 \mathrm{~mm})$ formed highest zone of inhibition Turbidometri showed the highest O.D. $(0.908 \mathrm{~nm})$ by Copper oxy chloride and Neem oil showed maximum inhibition of growth with O.D. (0.842 nm). Biotic stress (pathogen) induced protein response was studies by using SDS-PAGE method after protein extraction from $X A P$, healthy $P$. granatum $L$. and infected $P$. granatum $L$. The protein band pattern showed the unique band no. 2 (Mol.Wt.66000 Da) in infected $P$. granatum $L$. as compared 
to the banding pattern of $X A P$ and healthy $P$. granatum $L$. The over expressed protein due to biotic stress could be useful as a marker for detection of the disease at the early stage and for control of the diseases after knowing the biochemical significance of the protein.

Keywords: Pomegranate; bacterial blight; Xanthomonas axonopodis pv. punicae; in vitro efficacy; antimicrobial activity; SDS-PAGE.

\section{INTRODUCTION}

Pomegranate (Punica granatum L.) belongs to the family Lythraceae, is an ancient, medical fruit and cash crop of Maharashtra. I $t$ is also grown in commercially in other state of india viz. Karnataka, Andhra Pradesh, Rajasthan, Gujarat, and Tamil Nadu [1]. India is one of the major producers of pomegranate in the world with average total production of 8 lakh tons per annum [2].

Many diseases occurred on the pomegranate plant out of them bacterial disease caused by the Xanthomonas axonopodis pv. punicae (Xap) strongly damaged the pomegranate production, including large economic losses to the Indian growers [3]. Bacterial disease cause substantial loss to the productivity of major crop plants. Unlike fungal disease, bacterial disease not control effectively through chemical methods.

The symptoms of the bacterial blight were observed on the leaves stems and fruits as small ( 2 to $5 \mathrm{~mm}$ ) in size, irregular, prominent water soaked spots, which later become black often leads to the breaking of branches and cracking of fruits, reducing to the market value of the fruit $[4,5]$.

It is gram negative, aerobic rods belonging to the family Pseudomonodaceae. The pathogen causes disease actively at high temperature (up to $32^{\circ} \mathrm{C}$ ) and high rainfall and humidity and $\mathrm{p}^{\mathrm{H}}$ at 7.0. The pathogen causes destruction of seedlings and adult plants and thus results in yield reduction. The aim of the study was to screen in vitro a range of antimicrobial agents and their efficacy against Xap and protein profiling; in laboratory conditions.

\section{MATERIALS AND METHODS}

\subsection{Collection and Isolation of Disease Sample}

The samples were collected from two different districts of Maharashtra viz. Ahmednagar and pune as per typical symptoms showed by plant externally. The fresh infected leaves samples were used for isolation employing tissue isolation method by using Nutrient Agar medium [6].

\subsection{Purification and Maintenance of Bacterial Culture}

The respective bacterial cultures were maintained on NA medium at room temperature by adopting subsequent subculturing at periodical, regular intervals. Three days old cultures were used for further studies [7].

\subsection{Identification of the Pathogen}

The identification of the pathogen involved in causing of oily spot in pomegranate was determined by conducting studies on its morphological $[8,9]$ and biochemical $[10,11]$ features of the pathogen as per standard microbiological procedures.

\subsection{Pathogenicity Test}

Veinlets of some leaves were injected with $48 \mathrm{~h}$ old bacterial suspension with the help of sterile Dispo Van syringe. Some plant leaves were inoculated by injuring the leaves with sharp needle and by cotton swabbing the bacterial suspension on injured leaves. The plant was kept for incubation. After $10-12$ days observations made for typical symptoms of bacterial blight on leaves, the organism was reisolated from artificially inoculated leaves of Pomegranate plants showing typical symptoms of disease. The re-isolation was carried out on NAS medium and the growth of organism was observed for next 23 days $[12,13]$.

\subsection{In vitro Efficacy of Different Chemicals and Plant Derived Oils against XAP by Using Paper Disc and Turbidiometric Method}

In vitro efficacy of different chemicals and oils was checked against Xanthomonas axonopodis pv. Punicae by using paper disc and turbidiometric method (Copper oxy chloride: 2500 ppm, 1000 ppm, Bronopol: 3000 ppm, 1000 ppm, Bordeaux mixture: 3000 ppm, 1000 ppm, Bactomycin: 1200 ppm, 1000 ppm, Clove 
oil: $100 \%$, Nilgiri oil: $100 \%$, Neem oil: $100 \%$ ) $[14,15]$.

\subsection{Isolation of Protein from Healthy and Infected Pomegranate Leaves}

Kumar et al. [16] standardized the protein isolation protocol from plant leaves.

\subsection{Isolation of Protein from Xanthomonas axonopodis pv. Punicae}

Bioera's teaching kit [17] described the protein extraction from bacteria and clear result was observed.

\section{Day I:}

i) The LB plates were inoculated with loopful stock culture of Xanthomonas axonopodis.

ii) The paltes were incubated overnight at $37^{\circ} \mathrm{C}$.

\section{Day II:}

iii) A single colony was picked from the LB plate and inoculated into $5 \mathrm{ml}$ LB Broth.

iv) The LB broth was incubated at $37^{\circ} \mathrm{C}$ on a shaker overnight.

\section{Day III:}

v) The overnight incubated $1 \mathrm{ml}$ ofculture was inoculatedinto $50 \mathrm{ml}$ of LB Broth (In a 500 $\mathrm{ml}$ conical flask).

vi) The culture flask was incubated at $37^{\circ} \mathrm{C}$ on the shaker, until cells reach mid log phase of growth that is $\mathrm{A} 600$ is 0.5 (approximately 4-5 hours).

vii) $5 \mathrm{ml}$ of the culture from step 6 was transferred into test tube.

viii) The $3 \mathrm{ml}(1.5 \mathrm{ml}$ at a time) of culture was centrifuged in $1.5 \mathrm{ml}$ vials at $8000 \mathrm{rpm}$ for 10 minutes. The supernatant was discarded at each time.

i) The cell pellets was resuspend in $100 \mu \mathrm{l}$ of cell lysis buffer.

ii) $25 \mu \mathrm{l}$ of protein loading dye was added to suspension and mixed gently.

iii) The samples were boiled in water bath for 20 minutes.

iv) The samples were centrifuged at 6000 to $8000 \mathrm{rpm}$ for 10 minutes.

v) The $50 \mu \mathrm{l}$ protein marker and $35 \mu \mathrm{l}$ of sample supernatant was loaded on to SDS-PAGE. vi) The SDS-PAGE was runat 50 volts until bromophenol blue reaches near the bottom of separation gel.

vii) Stained the gel with protein staining solution.

\section{RESULTS AND DISCUSSION}

\subsection{Collection and Isolation of Diseased Sample}

Bacterial blight infected samples were collected from Ahmednagar and Pune districts of Maharashtra, associated bacterium Xanthomonas axonopodis pv. punicae was isolated. Purified culture was maintained on NSA slants and coded as Xap I, Xap II respectively. [18].

\subsection{Identification of the Pathogen}

Morphological and biochemical characteristic viz., shape, colony colour, Gram reaction, starch hydrolysis, gelatein liquefaction, indole production, acid and gas production, $\mathrm{KOH}$, catalase test were performed and confirmed to identity the bacterium as Xanthomonas axonopodis pv. punicae and following Table 1 showed the morphological and biochemical test. $[19,20]$.

\subsection{Pathogenicity Test}

Pathogenicity test of isolates was confirmed by injecting bacterial solution to disease free pomegranate plant. Occurrence symptoms of bacterial blight symptoms on plant leaf confirmed pathogenicity test of isolates (Fig. 1). Bacterium was reisolated from infected plant to prove Koch's postulates [21].

\subsection{In vitro Efficacy of Different Chemicals and Plant Derived Oils against XAP by Using Paper Disc Method}

In order to assess the efficacy of chemicals and oils against two isolates of Xanthomonas axonopodis pv. Punicae an experiment was conducted and the evaluation was made by paper disc method. The data presented in (Table 2) revealed the significant differences among the different treatment. In the chemical treatment Bronopol were significantly superior in inhibiting the growth of bacteria $(18.6 \pm 0.7 \mathrm{~mm}, 25.6 \pm 1.6$ $\mathrm{mm}$ ) against Xap. Among the oils Clove oil showed maximum zone of inhibition 18.3 \pm 0.7 mm (Fig. 2) [22]. 


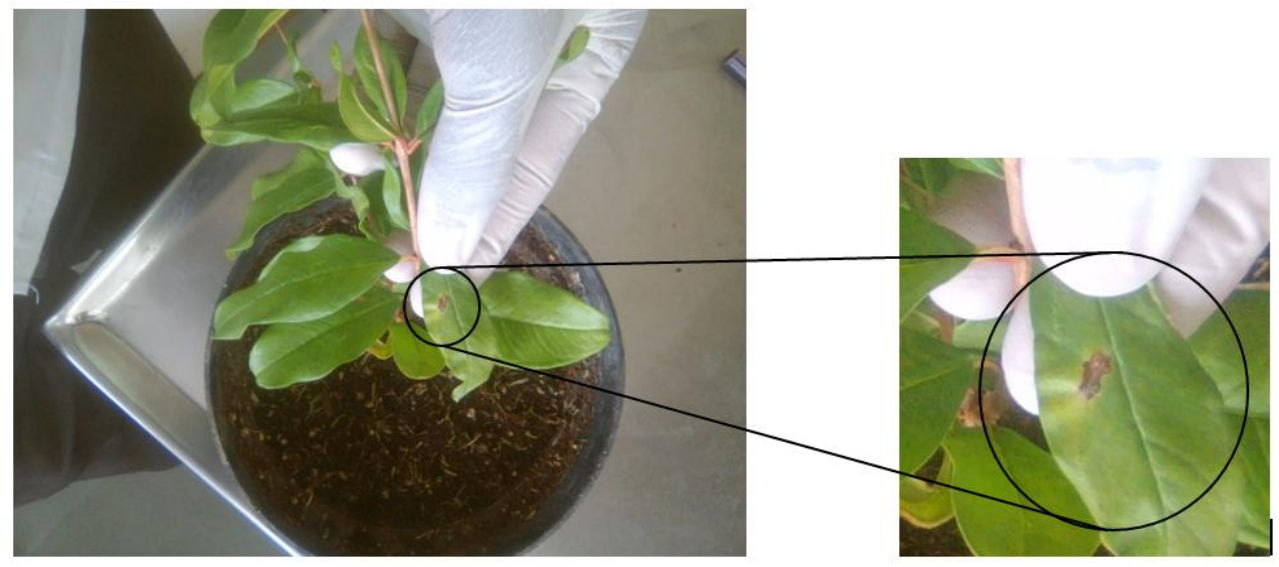

(a)

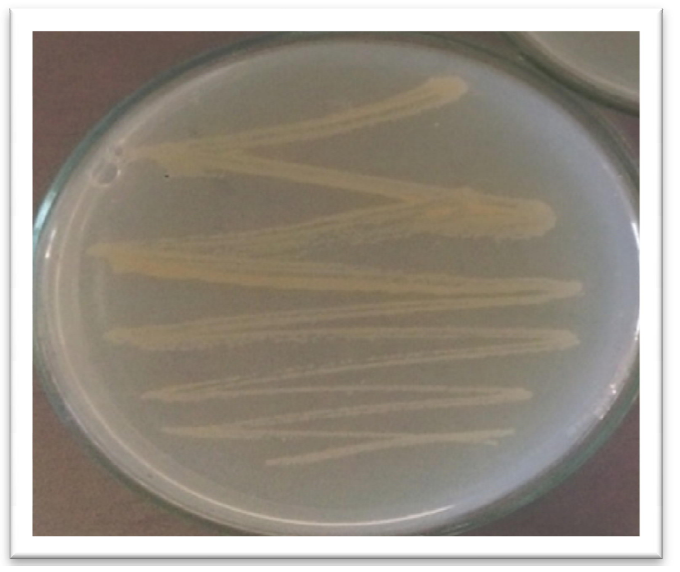

(b)

Fig. 1. (a) Symptoms of bacterial blight observed after 10-12 days of inoculation (b) Reisolated Xanthomonas axonopodis pv. punicae after pathogenicity test

\subsection{In vitro Efficacy of Different Chemicals and Plant Derived Oils against XAP by Using Turbidiometric Method}

Efficacy different chemicals and oils was tested turbidometrically. After 24 hours of incubation list O.D. $0.713 \mathrm{~nm}$ was exhibited by Bronopol(3000 ppm), followed by Copper oxy chloride (3000 $\mathrm{ppm}$ ) with O.D. $0.908 \mathrm{~nm}$ and Bordeaux (3000 ppm) $0.834 \mathrm{~nm}$ respectively whereas Bronopol (1000 ppm) with O.D $0.219 \mathrm{~nm}$ showed minimum inhibition of growth and Among the oils tested Neem oil showed maximum inhibition of growth with O.D. $0.842 \mathrm{~nm}$, followed by Clove oil with O.D. $0.810 \mathrm{~nm}$, Nilgiri oil showed minimum inhibition of growth among oils showed in following Table 3.

\subsection{Protein Isolation from Healthy Pomegranate Leaves, Infected Pomegranate Leaves and XAP I, XAP II Bacteria}

3.5.1 Data analysis of healthy pomegranate leaves, infected pomegranate leaves and bacteria

Following data analysis Table shows the actual position of bands on the gel as compared to the standard marker on the basis of molecular weights provided by BioEra's Teaching Kit.

The protein banding pattern showed the unique band no. 2 (Mol.Wt.66000 Da) in infected $P$. granatum $L$. as compared to the banding pattern of $X$. axonopodis pv. punicae and healthy $P$. granatum L. (Fig. 3) [23]. 
Table 1. Morphological and biochemical characteristics of Xanthomonas axonopodis pv. punicae isolates

\begin{tabular}{llll}
\hline Sr. No. & Morphological and biochemical test & XAP I & XAP II \\
\hline 1. & Colony color & Yellow & Yellow \\
2. & Gram's reaction & - ve & - ve \\
3. & Starch hydrolysis & +++ & ++ \\
4. & Indole production & ++ & + \\
5. & Catalase test & +++ & +++ \\
6. & KOH test & ++ & + \\
7. & Gelatin liquefaction & ++ & ++ \\
8. & Acid production & ++ & + \\
\hline \multicolumn{5}{r}{} & Negative, + Positive, Varying degree of + ve reaction $(+$ poor, ++ moderate,,+++ strong)
\end{tabular}

Table 2. Revealed the significant differences among the different treatment by paper disc method

\begin{tabular}{lllll}
\hline Sr. No. & Treatment & Concentration & $\begin{array}{l}\text { Zone of inhibition } \\
\text { produced by XAP I }\end{array}$ & $\begin{array}{l}\text { Zone of inhibition } \\
\text { produced by XAP II }\end{array}$ \\
\hline $\mathrm{T}_{0}$ & Control(+ve) water & $10 \mu \mathrm{l}$ & 00 & 00 \\
$\mathrm{~T}_{1}$ & Control(-ve) Ampicillin & $15 \mu \mathrm{l}$ & $17.9 \pm 0.6$ & $27.7 \pm 0.7$ \\
$\mathrm{~T}_{2}$ & Bronopol & $1000 \mathrm{ppm}$ & $10.8 \pm 0.4$ & $18.6 \pm 0.7$ \\
$\mathrm{~T}_{3}$ & Bordeaux & $1000 \mathrm{ppm}$ & $10.2 \pm 0.2$ & $9.3 \pm 0.1$ \\
$\mathrm{~T}_{4}$ & COC & $1000 \mathrm{ppm}$ & $12.1 \pm 0.3$ & $11.9 \pm 1.5$ \\
$\mathrm{~T}_{5}$ & Bactomycin & $1000 \mathrm{ppm}$ & $10.1 \pm 0.3$ & $13.2 \pm 0.9$ \\
$\mathrm{~T}_{6}$ & Bronopol & $3000 \mathrm{ppm}$ & $11.6 \pm 0.4$ & $25.6 \pm 1.6$ \\
$\mathrm{~T}_{7}$ & Bordeaux & $3000 \mathrm{ppm}$ & $9.7 \pm 0.7$ & $8.1 \pm .02$ \\
$\mathrm{~T}_{8}$ & COC & $2500 \mathrm{ppm}$ & $7.1 \pm 1.0$ & $9.2 \pm 0.4$ \\
$\mathrm{~T}_{9}$ & Bactomycin & $1200 \mathrm{ppm}$ & $11.2 \pm 0.4$ & $15.3 \pm 0.2$ \\
$\mathrm{~T}_{10}$ & Clove oil & $100 \%$ & $15.9 \pm 0.9$ & $18.3 \pm 0.7$ \\
$\mathrm{~T}_{11}$ & Neem oil & $100 \%$ & $13.4 \pm 1.6$ & $7.3 \pm 1.1$ \\
$\mathrm{~T}_{12}$ & Nilgiri oil & $100 \%$ & $8.3 \pm 0.9$ & $10.6 \pm 0.4$ \\
\hline
\end{tabular}

Table 3. Efficacy of chemicals and oils against Xanthomonas axonopodis pv punicae by turbidometric method

\begin{tabular}{|c|c|c|c|c|}
\hline Sr. No. & Treatment & Concentration & O.D. of culture & O.D. after $24 \mathrm{hrs}$ at $620 \mathrm{~nm}$ \\
\hline $\mathrm{T}_{0}$ & $\begin{array}{l}\text { Control(+ve)nutrient } \\
\text { broth }\end{array}$ & $1 \mathrm{ml}$ & & 00 \\
\hline $\mathrm{T}_{1}$ & Control (-ve) antibiotic & $500 \mu \mathrm{l}$ & & 0.324 \\
\hline $\mathrm{T}_{2}$ & Bronopol & 1000 ppm & & 0.219 \\
\hline $\mathrm{T}_{3}$ & Bordeaux & 1000 ppm & 0.998 & 0.337 \\
\hline $\mathrm{T}_{4}$ & $\mathrm{COC}$ & 1000 ppm & & 0.410 \\
\hline $\mathrm{T}_{5}$ & Bronopol & 3000 ppm & & 0.713 \\
\hline $\mathrm{T}_{6}$ & Bordeaux & 3000 ppm & & 0.834 \\
\hline $\mathrm{T}_{7}$ & $\mathrm{COC}$ & 3000 ppm & & 0.908 \\
\hline $\mathrm{T}_{8}$ & Clove oil & $100 \%$ & & 0.810 \\
\hline $\mathrm{T}_{9}$ & Neem oil & $100 \%$ & & 0.842 \\
\hline $\mathrm{T}_{10}$ & Nilgiri oil & $100 \%$ & & 0.392 \\
\hline
\end{tabular}

Table 4. Data analysis of healthy pomegranate leaves, infected pomegranate leaves and bacteria

\begin{tabular}{lllllll}
\hline $\begin{array}{l}\text { Sr. } \\
\text { No. }\end{array}$ & $\begin{array}{l}\text { Standard } \\
\text { marker } \\
\text { (Band no) }\end{array}$ & $\begin{array}{l}\text { Molecular } \\
\text { weight }\end{array}$ & $\begin{array}{l}\text { Healthy plant } \\
\text { (Band no) }\end{array}$ & $\begin{array}{l}\text { Infected plant } \\
\text { (Band no) }\end{array}$ & $\begin{array}{l}\text { XAP I } \\
\text { proteins } \\
\text { (Band no) }\end{array}$ & $\begin{array}{l}\boldsymbol{X} \boldsymbol{P} \boldsymbol{I I} \\
\text { proteins } \\
\text { (Band no) }\end{array}$ \\
\hline 1. & 1 & 97,400 & Absent & Absent & Absent & Absent \\
2. & 2 & 66,000 & Absent & Present & Absent & Absent \\
3. & 3 & 43,000 & Present & Present & Absent & Absent \\
4. & 4 & 29,000 & Present & Present & Absent & Absent \\
5. & 5 & 20,100 & Present & Present & Present & Present \\
6. & 6 & 14,300 & Present & Present & Present & Present \\
\hline
\end{tabular}



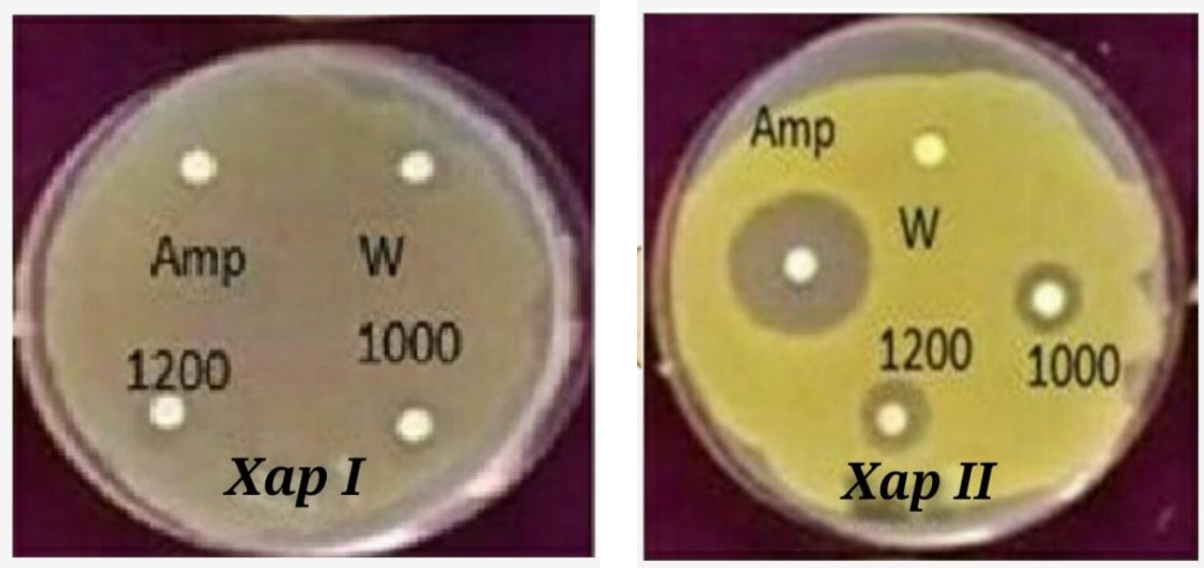

(a) Bactomycin
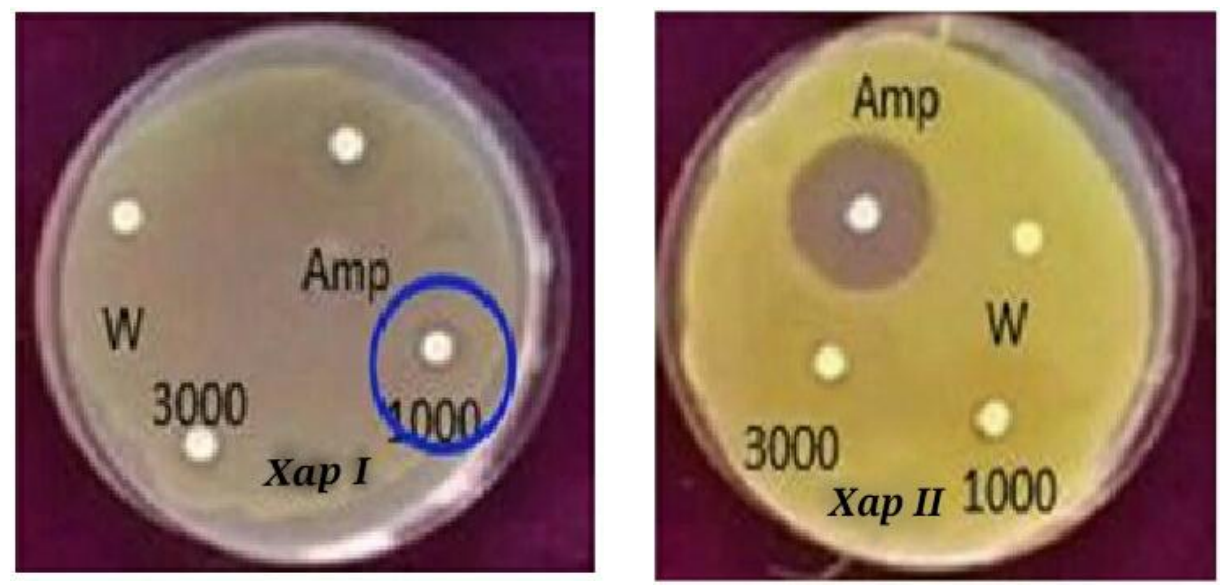

(b) Bordeaux
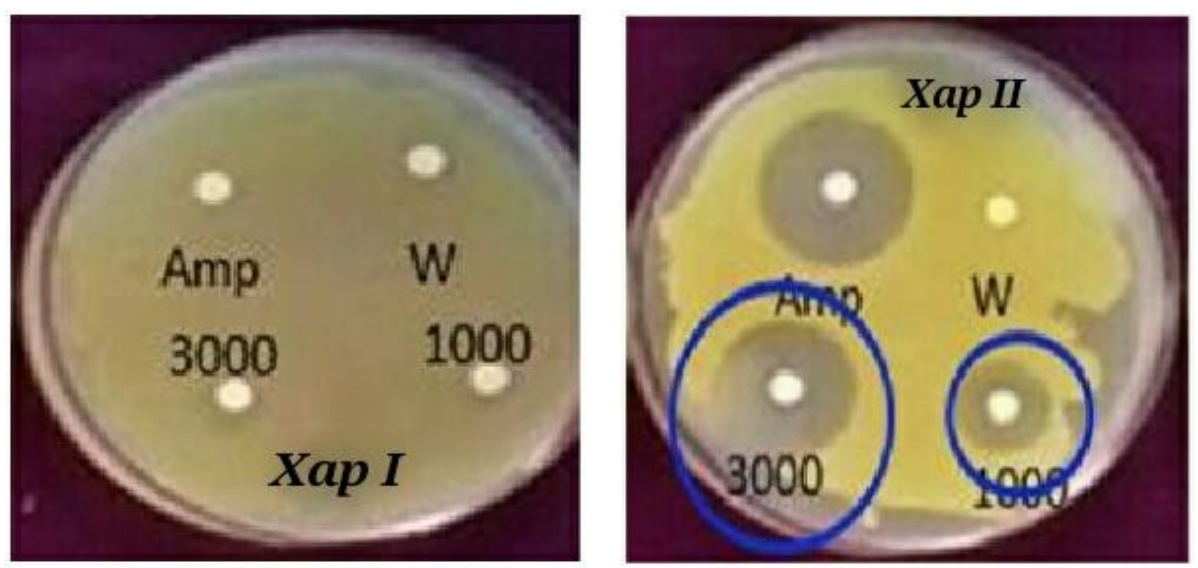

(c) Bronopol 

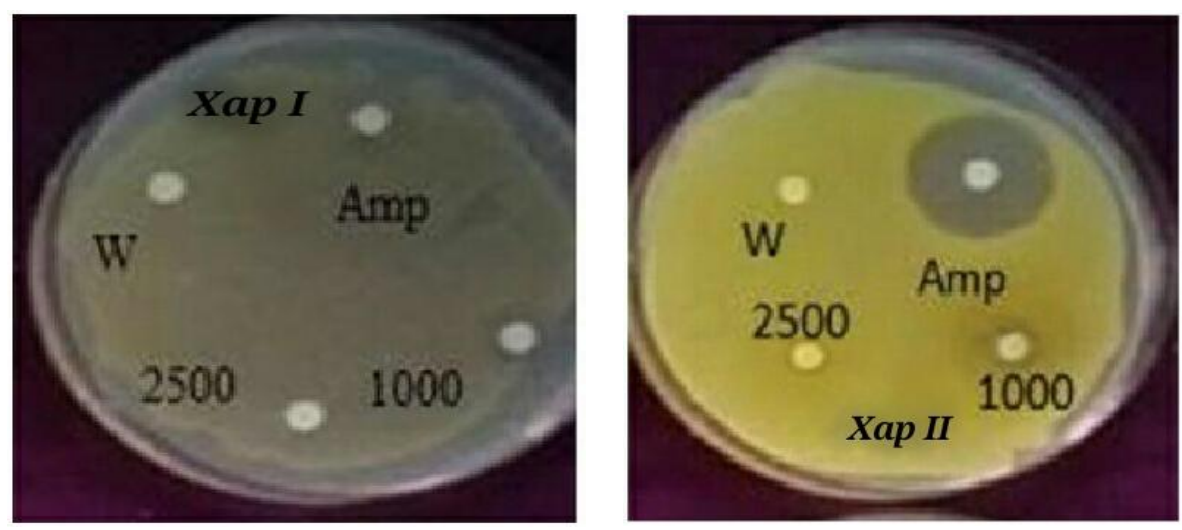

(d) Copper oxychloride
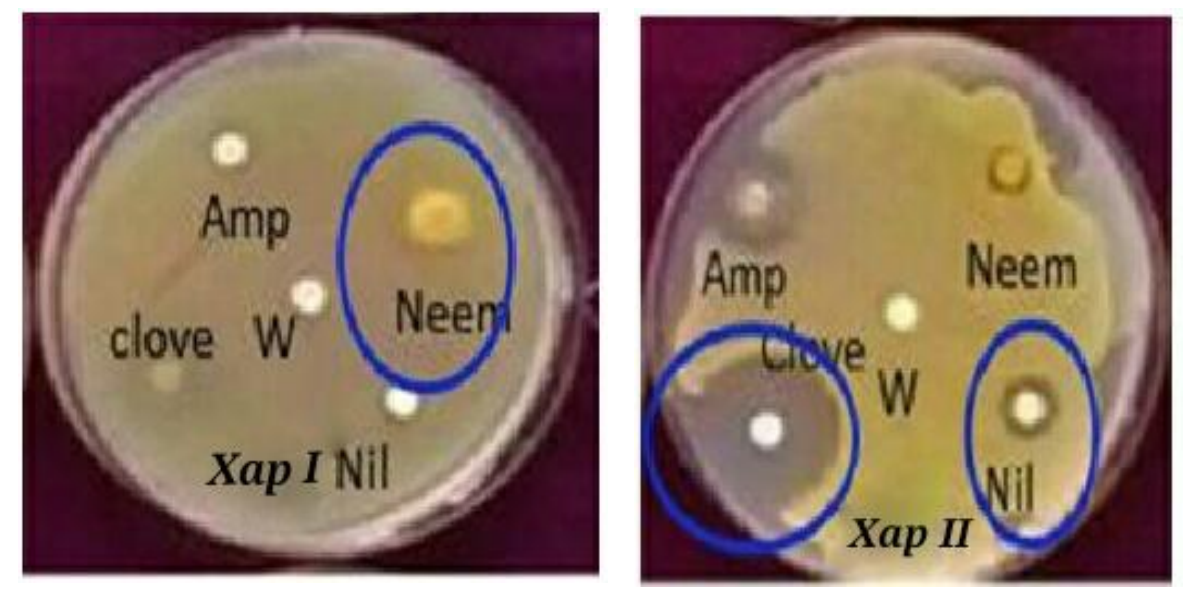

(e) Oils

Fig. 2. Efficacy of different chemicals and oils against Xanthomonas axonopodis pv. Punicae by Paper disc method

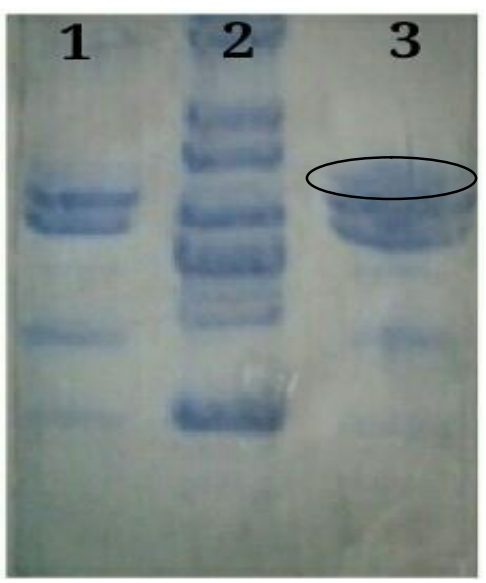

(a)

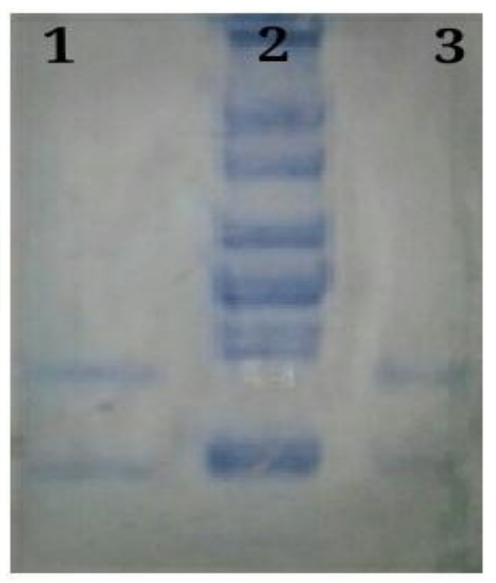

(b)

Fig. 3. (a) Isolated proteins of 1) Healthy, 2) Marker, 3) Infected leaves (b) 1) Xap I, 2) Marker and 3) Xapll Bacteria (Xanthomonas axonopodis pv. punicae) 


\section{CONCLUSION}

In the current study the pathogen infected samples identified as infected with $X A P$ was through morphological, biochemical characterization and Pathogenicity test. Efficacy of different chemicals and oils were tested by disc diffusion assay and turbidometrically. Bronopol $3000 \mathrm{ppm}(25.6 \pm 1.6 \mathrm{~mm})$ formed highest zone of inhibitionand Clove oil formed highest zone of inhibition $(18.0 \pm 0.7 \mathrm{~mm})$. Turbidometri showed the highest O.D. (0.908 $\mathrm{nm})$ by Copper oxy chloride and Neem oil showed maximum inhibition of growth with O.D. $(0.842 \mathrm{~nm})$.

Biotic stress (pathogen) induced protein response was studies by using SDS-PAGE method after protein extraction from $X A P$, healthy $P$. granatum $L$. and infected $P$. granatum $L$. The protein banding pattern showed the unique band no. 2 (Mol.Wt.66000 Da) in infected $P$. granatum $L$. as compared to the banding pattern of $X$. axonopodis pv. punicae and healthy $P$. granatum $L$. The over expressed protein due to biotic stress could be useful as a marker for detection of the disease at the early stage and for control of the diseases after knowing the biochemical significance of the protein.

\section{COMPETING INTERESTS}

Authors have declared that no competing interests exist.

\section{REFERENCES}

1. Manjula N, Sheikh MK, Teggi MY. Bacterial blight management practice adopted by farmers ISHS ACTA Horticulture 890: International symposium on pomegranate and minor-including Mediterranean-Fruits; 2009.

2. Vauterin L, Haste B, Kersters K, Swings J. Reclassification of Xanthomonas. Int. J. Syst. Bacterial. 1995;45:475-489.

3. Mondal KK, Sharma J. Bacterial blight: An emerging threat to pomegranate export. Ind. Farm. 2009;59:22-23.

4. Rangaswamy G. Pomegranate. In: bacterial plant disease in India. Asia publication house, Bombay. 1962;830.

5. Manjula CP, Khan ANA. Incidence of bacterial blight of pomegranate (Punica granatum L.) in Karnataka. Paper presented at the Annu. Meet. Symp. Plant disease scenario in southern India, held at Bangalore; 2002.

6. Antre SH, Gadhe SK, Abhang PB, Autade $\mathrm{RH}$. In vitro efficacy of different chemicals, botanicals and bioagent Against Xanthomonas axonopodis pv. punicae, Int. J. Pure App. Biosci. 2016;4(3):112118.

Available:http://dx.doi.org/10.18782/23207051.2310

7. Kanwar ZS. A note on bacterial disease of Pomegranate (Punica granatum L.) in Haryana. Haryana J. Horti. Sci. 1976;5: 177-180.

8. Ryan RP, Vorhölter FJ, Potnis N, Jones JB, Van Sluys MA, Bogdanove AJ, Dow JM. Pathogenomics of Xanthomonas: Understanding bacterium-plant interactions. Nature Reviews Microbiology. 2011;9(5): 344-355.

9. Kishun R. Bacterial diseases of fruits. In: Chadha KL, Parek OP (Eds). Advances in Horticulture-Fruit crops, Malhotra Publishing House, New Delhi, India. 1993; 31389-1404.

10. Duche TR, Omoigui L, Iheukwumere CC. Variations among Xanthomonas axonopodis pv. vignicola isolates in Benue State, Nigeria. International Journal of Innovation and Scientific Research. 2015; 13(1):271-278.

11. Giri MS, Prasanthi Kulkarni S, Benagi VI, Hegde YR. Biochemical and molecular variability among Xanthomonas axonopodis pv. Punicae strains, the pathogen of pomegranate bacterial blight. Indian Phytopathol. 2011;64(1):1-4.

12. Popovic $T$, Josic $D$, Starovic $M$, Milovanovic $P$, Dolovac $N$, Postic $D$, Stankovic S. Phenotypic and genotypic characterization of Xanthomonas campestris strains isolated from cabbage, kale and broccoli. Archives of Biological Science. 2013;65:585-593.

13. Abdo-Hasan M, Khalil H, Debis B, Mir Ali N. Molecular characterization of Syrian races of Xanthomonas axonopodis pv. malvacearum. Journal of plant Pathology. 2008;431-439.

14. Kizil S, Uyar F, Sagir A. Antibacterial activities of some essential oils against plant pathogens. Asian Journal of Plant Sciences; 2005.

15. Pawar $\mathrm{M}$, kadam $\mathrm{M}$, Nirichan BK. In vitro control of bacterial blight causing organism (Xanthomonas axonopodis pv. punicae) of pomegranate. Journals of Environmental 
Research and Development. 2014;8(3a): 568.

16. Kumar Suresh, Vinutha T, Archana Singh, Rai RD et al. Training manual plantomicsemerging tools and techniques for crop Improvement; 2015.

17. Bio Era Life Sciences Pvt. Ltd., Pune. Teaching Kit, Total Protein Extract Kit (From Bacteria) [Brochure]. Pune, Maharashtra: Author. Catalog number BTK 130934; 2017.

18. Bradbury JF. Isolation and preliminary study of bacteria from plants. PANS Pest Articles \& News Summaries. 1970;16(4): 632-637.

19. Gamangatti RB, Patil MB. Biochemical studies on Xanthomonas axonopodis pv. punicae causing bacterial blight of pomegranate. International Journal of Plant Protection. 2013;6(2):401404.
20. Bhardwaj NR, Upadhyay V, Nagar $M$. Biochemical characterization of Xanthomonas axonopodis pv. citri, causal agent of citrus canker; 2014.

21. Yenjerappa ST. Epedemiology and management of bacterial blight of pomegranate caused by Xanthomonas axonopodis pv.punicae (Hingorani and Singh) Vauterin et al. Ph. D. Thesis, Univ. Agri. Sci. Dharwad (India). 2009;147.

22. Meerts, Fadavi et al. In vitro control of bacterial blight causing organism (Xanthomonas axonopodis pv. Punicae) of pomegranate Journal of Environmental Research and Development. 2009;8(3a): 568.

23. Walker JM. Electrophoretic techniques. In Principles and Techniques of Biochemistry and Molecular Biology ( $6^{\text {th }}$ ed.). New York: Cambridge University Press. 2005;449485.

(c) 2019 Gaikwad et al.; This is an Open Access article distributed under the terms of the Creative Commons Attribution License (http://creativecommons.org/licenses/by/4.0), which permits unrestricted use, distribution, and reproduction in any medium, provided the original work is properly cited.

Peer-review history:

The peer review history for this paper can be accessed here: http://www.sdiarticle3.com/review-history/41166 